\title{
HAART: a risk factor for development of porphyria cutanea tarda?
}

\author{
Fred Bernardes Filho ${ }^{[1]}$, Maria Victória Pinto Quaresma Santos ${ }^{[1]}$, Felipe Nazareth de Matos Pinto de Carvalho ${ }^{[1]}$, \\ Carlos Gustavo Carneiro de Castro ${ }^{[1]}$, Elisabete Dobao ${ }^{[1]}$, Marcelo Rosandiski Lyra ${ }^{[3]}$, \\ Vinícius de Menezes ${ }^{[2]}$ and José Augusto da Costa Nery ${ }^{[1],[2]}$
}

[1]. Ambulatório de Doenças Sexualmente Transmissíveis, Instituto de Dermatologia Prof. Rubem David Azulay, Santa Casa da Misericórdia do Rio de Janeiro, Rio de Janeiro, RJ. [2]. Laboratório de Hanseníase, Instituto Oswaldo Cruz, Fundação Oswaldo Cruz, Rio de Janeiro, RJ. [3]. Instituto de Pesquisa Clínica Evandro Chagas, Fundação Oswaldo Cruz, Rio de Janeiro, RJ.

\section{ABSTRACT}

Porphyria cutanea tarda (PCT) is caused by inherited or acquired partial deficiency of the uroporphyrinogen-decarboxylase (Uro-D) enzyme activity. It is the most common form of porphyria. The main triggering factors to the development of porphyria cutanea tarda are alcohol, hepatitis $\mathrm{C}$ virus and human immunodeficiency virus. There are several reports of PCT associated with drugs, among them, antiretroviral therapy. We describe three HIV-positive patients, which showed photosensitivity as well as the emergence of tense blisters on sun-exposed areas during the use of highly active antiretroviral therapy (HAART) and discuss the possibility of PCT after the use of these drugs by those patients.

Keywords: Porphyria cutanea tarda. HAART. HIV.

\section{INTRODUCTION}

Porphyria cutanea tarda (PCT) is caused by inherited or acquired partial deficiency of the uroporphyrinogen-decarboxylase (Uro-D) enzyme activity. It is the most common form of porphyria and is prevalent in men over 40 year's old ${ }^{1}$. Porphyria cutanea tarda can be divided into four types according to its characteristics. The sporadic or acquired form (type I), the most common type of PCT, is characterized by decreased hepatic Uro-D enzymatic activity during the active disease state. This type of PCT is commonly induced by alcohol, estrogen, iron, drugs, hepatitis $C$ virus, human immunodeficiency virus, systemic lupus erythematosus or chemical materials. The hereditary form of PCT (type II) is an autosomal dominant disorder with genetic mutations of the Uro-D gene and it is associated with a family history, although most of the gene carriers are asymptomatic. Recent reports suggest that there is a relationship between hemochromatosis (HFE) gene mutation and PCT types I or II. The toxic form of PCT (type III) is characterized by its sporadic nature with a familial history. Hepatoerythropoietic porphyria (HEP), the fourth type of PCT, is caused by a homozygous defect of Uro- $D^{2-4}$.

The main triggering factors that often contribute to the development of porphyria cutanea tarda are alcohol, hepatitis $C$ virus (HCV) and human immunodeficiency virus (HIV) ${ }^{5}$. There are several reports of porphyria cutanea tarda associated with drugs, among them, the antiretroviral therapy. Although drugs that increase porphyrin synthesis in the liver commonly exacerbate acute intermittent porphyria (AIP), they may be related to $\mathrm{PCT}^{6}$.

Celesia BM et al. report the onset of porphyria cutanea tarda in HIV-infected patients after initiation of tipranavir/ritonavir. After withdrawal of these drugs associated with chloroquine $125 \mathrm{mg}$ twice

Address to: Dr. Fred Bernardes Filho. Ambulatório DST/Instituto de Dermatologia Prof. Rubem David Azulay. Rua Marques de Caxias 9, 24030-050 Niterói, RJ, Brasil. Phone: 5521 9826-7765

e-mail: f9filho@gmail.com

Received in 02/01/2012

Accepted in 03/05/2012 a week and photoprotection remission was observed ${ }^{7}$. Roca B et al. report the appearance of PCT three days after the patient started using nelfinavir. This drug was discontinued, weekly phlebotomies were initiated and the lesions disappeared within a few days ${ }^{8}$. Ong ELC et al. report the emergence of tense PCT blisters after initiation of azidothymidine therapy. This drug was discontinued and there was spontaneous resolution in a few weeks. With the reintroduction of azidotimidina (AZT) after clinical improvement a recurrence of bubbles was observed ${ }^{9}$. In our opinion, this case strongly supports the hypothesis that a direct causative relationship exists between highly active antiretroviral therapy (HAART) and the development of PCT.

We describe three HIV-positive patients, which showed photosensitivity as well as the emergence of tense blisters on sunexposed areas. The patients were undergoing antiretroviral therapy.

In various drug databases searched, drugs are classified into categories reflecting the risk of provoking porphyria and range from non-porphyrinogenic drugs, which can be used safely, to the class of high-risk porphyrinogenic drugs ${ }^{10-12}$.

This report is to demonstrate the development of porphyria cutanea tarda by drugs used in HAART in HIV patients.

It is a retrospective study. We conducted a medical literature search in PubMed with the keywords porphyria cutanea tarda, HAART, HIV and identified in the last 24 years, 3 cases of PCT occurring in patients receiving HAART therapy. In addition we searched the drug databases of The Norwegian Porphyria Centre (NAPOS), The American Porphyria Foundation (APF) and The Brazilian Association of Porphyria (ABRAPO). We report on three HIV-positive patients, one from the Ambulatório de Doenças Sexualmente Transmissiveis, Instituto de Dermatologia Prof. Rubem David Azulay (IDPRDA), Santa Casa de Misericórdia, Rio de Janeiro, one from the Laboratório de Hanseníase, Instituto Oswaldo Cruz, Fundação Oswaldo Cruz (FIOCRUZ), and the other from Instituto de Pesquisas Clínicas Evandro Chagas (IPEC). Data were collected in the period from October 2007 to December 2011.

To date, 6 cases of PCT, including the three cases presented here, possibly associated with HAART have been reported in 
the literature. Clinical summaries of these patients are provided in Table 1. The interval from the first administration of HAART treatment to the onset of PCT was variable (ranging from 3 days to 4 months). All patients received treatment for PCT: two used chloroquine and topical skin photoprotection, one initiated weekly phlebotomies and stopped HAART and the other only stopped HAART. All patients that stopped HAART experienced complete resolution. Our three patients were maintained on HAART and continued to have symptoms. It is important to notice that the three patients in whom the symptoms continued without recovery had blisters on sun exposed areas.

\section{CASE REPORT}

\section{Case 1}

A 49-year-old HIV-infected man presented a skin reaction that consisted of vesicles and bullae on sun-exposed areas, especially the dorsa of the hands. The patient had taken lamivudine (3TC), tenofovir disoproxil fumarate (TDF), lopinavir/ritonavir (LPV/R), from October 2009 to March 2011 when he began an association with efavirenz (EFV). Eight weeks later, he started presenting the appearance of vesicles and bullae on sun-exposed areas, especially on the backs of the hands. On skin examination, friable skin areas were observed with tense blisters on the hands and feet as well as hypertrichosis and hyperpigmentation on the face (Figures 1A and 1B). Despite implementing more anti-invective drugs, such as raltegravir and enfuvirtide, blood analysis showed that the CD4 cell count was 32 cells $/ \mathrm{mm}^{3}$, HIV RNA (ribonucleic acid) viral load was 38,602 copies/ml, uroporphyrin level $4,425 \mu \mathrm{g} /$ day: (reference value less - RV: inf.: $60 \mu \mathrm{g} / 24 \mathrm{~h}$ ) and

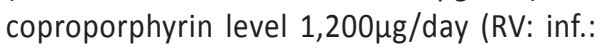
$120 \mu \mathrm{g} / 24 \mathrm{~h}$ ) were markedly increased.

\section{Case 2}

A 57-year-old male, born and dwelling in Rio de Janeiro, HIV positive since August 2008. The patient had taken AZT, 3TC and EFV from August 2008 to December 2010. Due to treatment failure the previous drug scheme was replaced by TDF, 3TC, atazanavir (ATV) and ritonavir (RTV). Eleven weeks after the change of medications the patient's CD4 count was 205 cells $/ \mathrm{mm}^{3}$ and viral load 184,924 copies/ml. At that time the patient presented skin fragility and bullae mainly on the dorsal skin of the foot (Figures 1C and 1D).

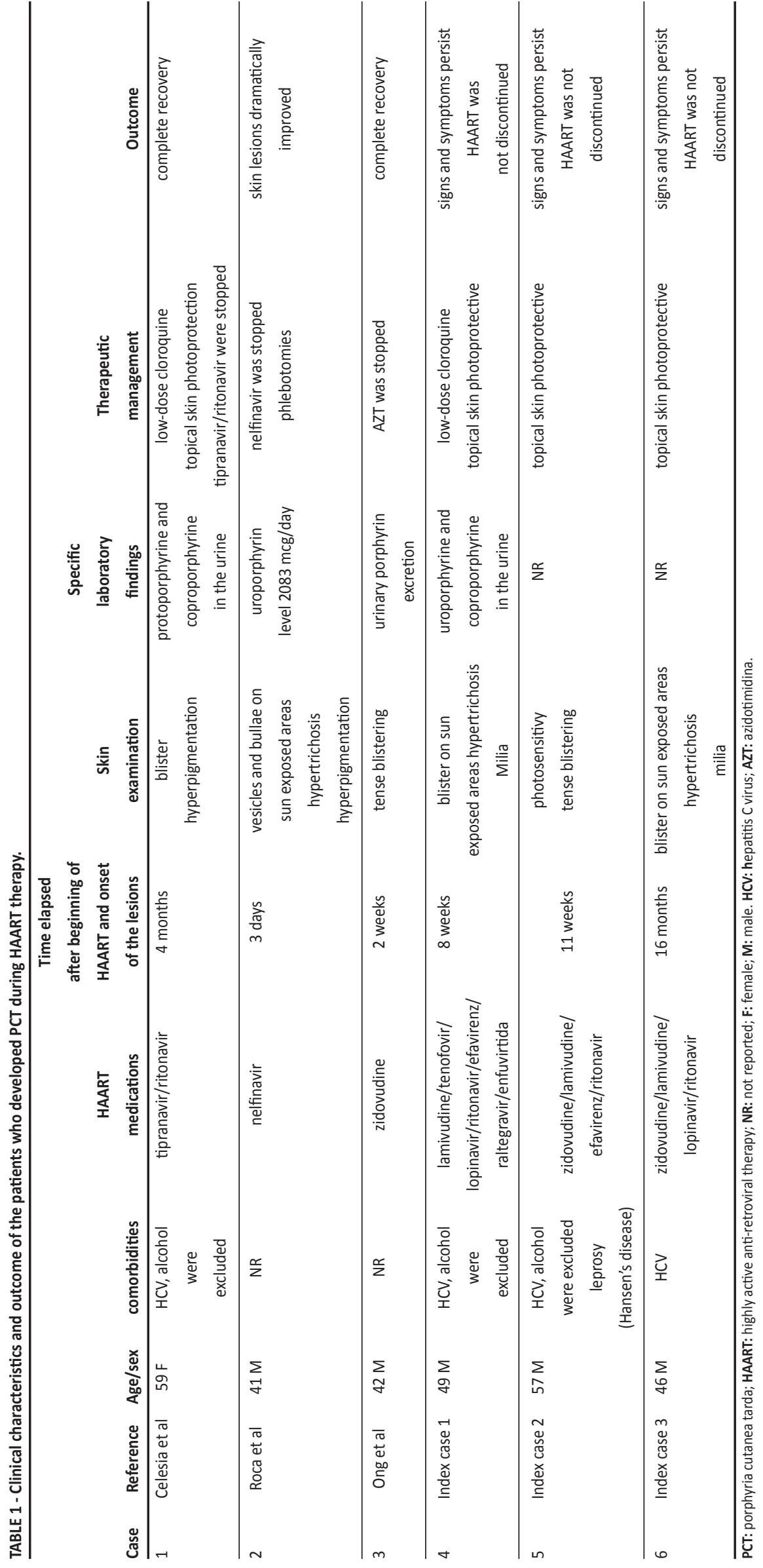




\section{Case 3}

A 46-year-old male, born and dwelling in Rio de Janeiro, HIV positive since October 2007, with previous HAART composed by TDF, 3TC and EFZ. In May 2009 genotype-guided change of the drug scheme for ZDV, 3TC and LPV/R was indicated because of treatment failure. In October 2010, the patient presented photosensitivity, skin tanning, facial hypertrichosis, as well as the presence of tense blisters, scarring and formation of milium distributed diffusely, but predominating on the back of the hands and feet (Figures 1E, 1F and 1G). The CD4 count was 158 cells $/ \mathrm{mm}^{3}$ and the HIV viral load was undetectable at the onset of the skin lesions. Anti HCV was positive and hepatitis B markers were negative.

The examination of the patient's case 1 urine with a Wood's lamp revealed coral pink fluorescence (Figure $\mathbf{1 H}$ ) as well as the patient's case 3 urine (Figure 11)

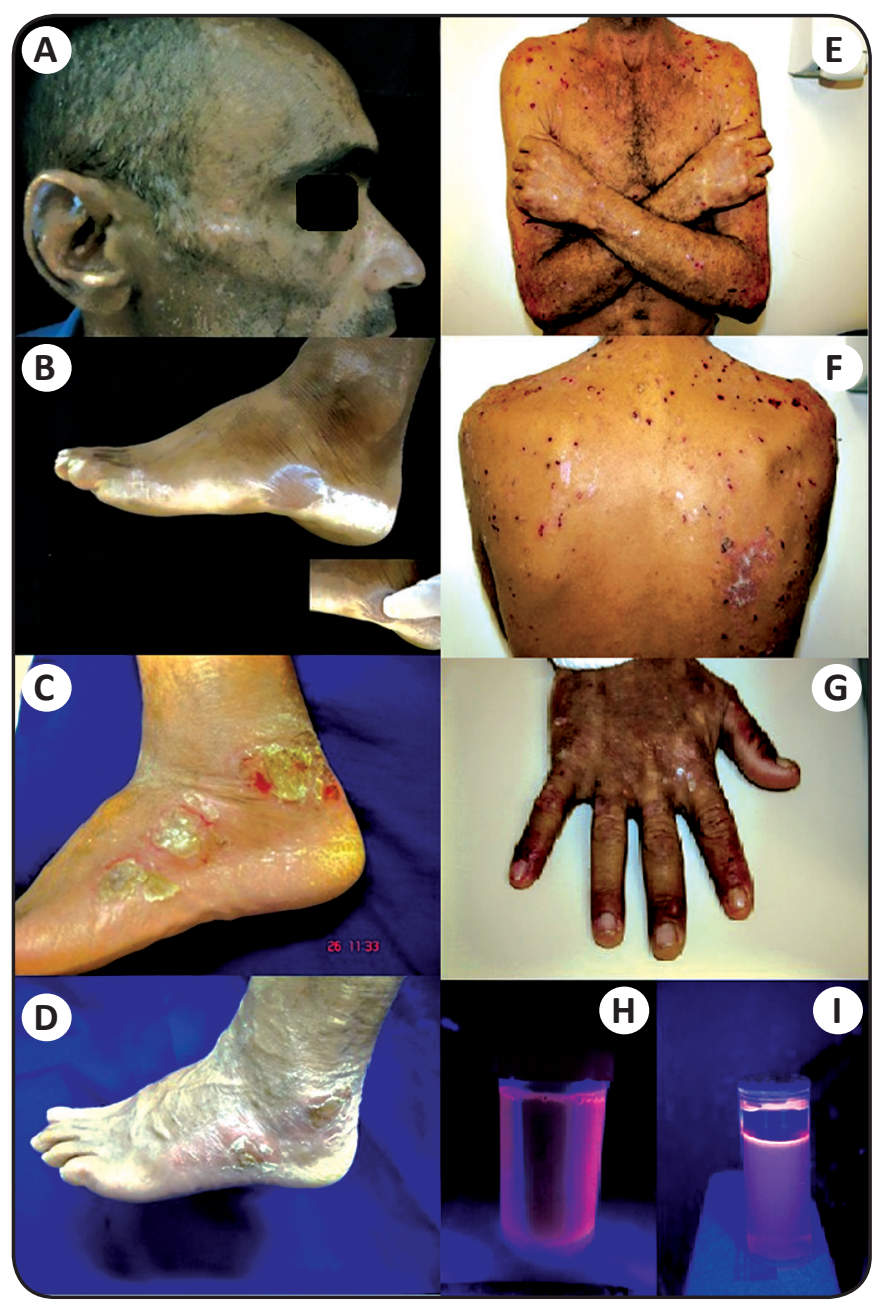

FIGURE 1 - Clinical features of patients 1 (A-B), 2(C-D), 3 (E-G) and the examination of the patient's urine with a Wood's lamp (H-I). A: Hypertrichosis and hyperpigmentation on the face. B: Tense blisters of the left foot; C-D: Skin fragility and bullae on the dorsal skin of the left foot. E-G: Photosensitivity, skin tanning, scarring and formation of milium; H: Coral pink fluorescence patient's case 1 urine at Wood's lamp; I: Coral pink fluorescence patient's case 3 urine at Wood's lamp.

\section{DISCUSSION}

Porphyria cutanea tarda is an iron-related disorder that results from decreased activity of hepatic uroporphyrinogen decarboxylase (Uro-D), the fifth enzyme of the heme synthetic pathway. This condition develops when hepatic Uro-D activity becomes less than $20 \%$ of normal. When Uro-D becomes markedly deficient in the liver, porphyrins accumulate and spill out into the blood, from where they may be either excreted into the urine, or deposited in various tissues around the body. When these porphyrins are deposited in the skin, they can absorb light. The porphyrins that accumulate in PCT are unable to store the energy of the light. This energy is released into the skin in photochemical reactions that cause damage to the skin. Thus persistent exposure to light leads to skin damage, blistering, and scarring.

The association of porphyria cutanea tarda to HIV infection is well recognized, although not completely understood. Has been suggested that HIV might alter the porphyrin metabolism, interfering with the function of the cytochrome P450.

Pseudoporphyria is clinically similar to PCT, but usually lacks the biochemical abnormalities, and is difficult to distinguish clinically and histologically. Occurs in association with uremia, hemodialysis, and certain drugs such as naproxen, tetracyclines, furosemide, sulfonamides, oxaprozin, cyclosporin, inhibitors of cyclooxygenase (COX) and acitretin.

When searching in various drug databases, it is noteworthy that antiviral medications, such as protease inhibitor and non-nucleoside reverse transcriptase inhibitor classes, have a high porphyrinogenic risk, so patients taking these medications should be monitored. It is well established scientifically that some medications used in HAART, for example, nucleoside reverse transcriptase inhibitors, can develop PCT in a greater or lesser porphyrinogenic degree.

There is gradual improvement after identifying and suspending this disease's trigger. Phlebotomy is the treatment of choice for uncomplicated forms of porphyria cutanea tarda. One of its contra-indications is HIV infection. Antimalarial medication, such as chloroquine, can be used in low doses. Hydroxychloroquine is not widely used and is associated with early relapse.

To prevent recurrence, the patients must be monitored for urinary porphyrin dosage because porphyrinuria precedes dermatological manifestations. Therefore, HIV-positive patients that present photosensitivity, skin fragility or facial hypertrichosis must undergo porphyrin dosage tests and sunscreen is recommended.

Considering the rarity of this association along with the relatively short follow-up of the reported cases, available data are insufficient to extract firm conclusions about the follow-up of these patients. However, as outlined in Figure 2, we suggest that patients being treated with HAART should be closely monitored for the development of PCT signs and symptoms. If clinical and laboratory evaluation leads to the diagnosis of PCT, institution of low-dose oral chloroquine treatment and topical skin photoprotective treatment in addition to considering the possibility of discontinuation of the medication should be a priority.

Therefore, it is important to assess patients on HAART because we believe that cases of porphyria cutanea tarda maybe under-diagnosed or diagnosed nonspecifically as cutaneous adverse reactions. 


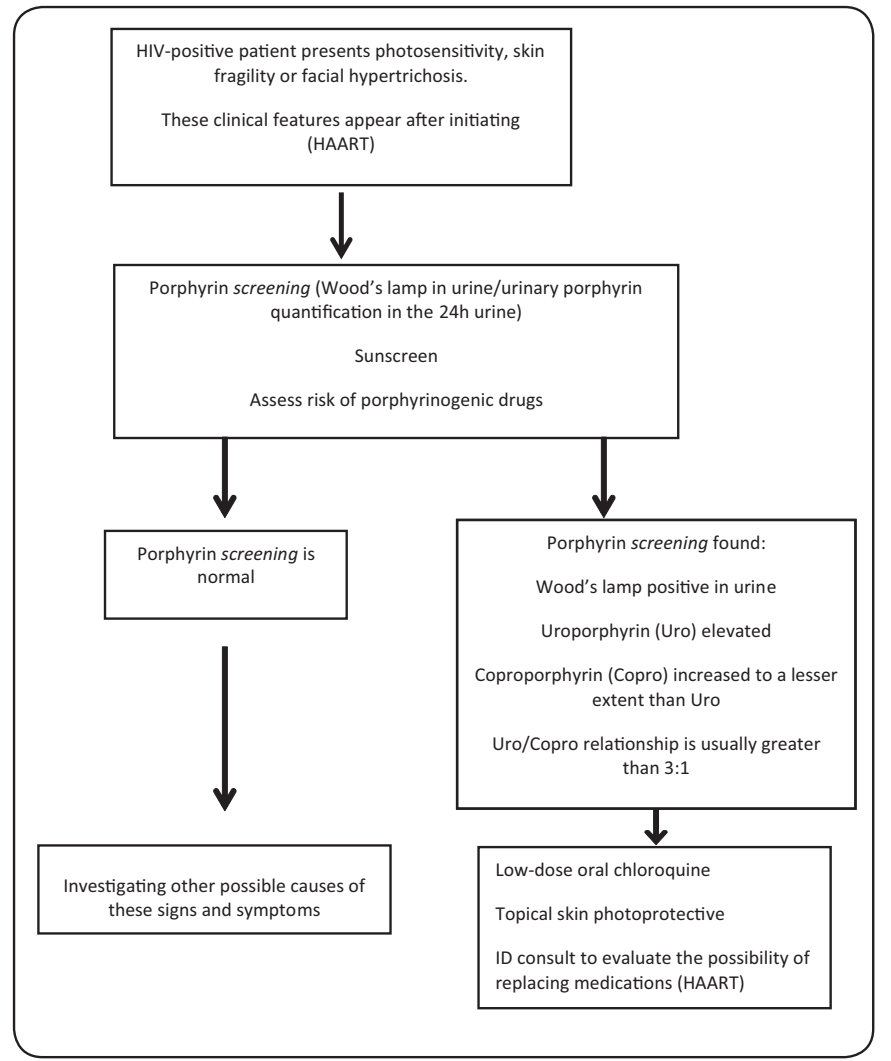

FIGURE 2 - Algorithm for HIV-positive patient using HAART with features of porphyria cutanea tarda.

HIV: human immunodeficiency virus; HAART: highly active antiretroviral therapy.

\section{ABSTRACT IN PORTUGUESE}

\section{HAART: fator de risco para desenvolvimento de porfiria cutânea tarda?}

Porfiria cutanea tarda (PCT) é causada pela deficiência parcial, adquirida ou hereditária, da atividade da enzima uroporfirinogeniodecarboxilase (Uro-D). É a forma mais comum de porfiria. Os principais fatores desencadeantes para o desenvolvimento da porfiria cutânea tarda são o álcool, vírus da hepatite C e vírus da imunodeficiência humana. Há vários relatos de PCT associada a drogas, entre elas, à terapia antirretroviral. Descrevemos três pacientes HIV-positivos, que mostraram fotossensibilidade, bem como o surgimento de bolhas tensas em áreas fotoexpostas durante o uso da highly active antiretroviral therapy (HAART) e discutimos a possibilidade de ocorrência PCT com o uso desses medicamentos.

Palavras-chaves: Porfiria cutanea tarda. HAART. HIV.

\section{REFERENCES}

1. Vieira FMJ, Martins JEC. Porfiria cutanea tardia. An Bras Dermatol 2006; 81:573-584

2. Jalil S, Grady JJ, Lee C, Anderson KE. Associations among Behavior-Related Susceptibility Factors in Porphyria Cutanea Tarda. Clin Gastroenterol Hepatol 2010; 8:297-302.

3. Lee KG, Hyun JJ, Seo YS, Keum B, Yim HJ, Jeen YT, et al. Liver cirrhosis induced by porphyria cutanea tarda: a case report and review. Gut Liver 2010; 4:551-555.

4. Oliveira Júnior JV, Paiva DLM, Rocha SFVCB, Valente N. Porfiria cutânea tardia. Relato de dois casos. Rev Bras Clin Med 2010; 8:286-289.

5. Lisboa Neto G, Tengan FM, Cavalheiro NP, Barone AA. Influência da infecção pregressa pelo vírus da hepatite $B$ na fibrose hepática em portadores de hepatite C crônica: avaliação retrospectiva de uma série de casos. Rev Soc Bras Med Trop 2010; 43:416-420.

6. The American Porphyria Foundation (APF). Porphyria Cutanea Tarda [Internet]. Houston, USA: APF; 2010. [Cited 2012 January 31]. Available from: www. porphyriafoundation.com/fo-healthcare-professionals/types-of-porphyria/PCT/.

7. Celesia BM, Onorante A, Nunnari G, Mughini MT, Mavilla S, Massimino SD, et al. Porphyria cutanea tarda in an HIV-1-infected patient after the initiation of tipranavir/ritonavir: case report. AIDS 2007; 21:1495-1496.

8. Roca B, Lapuebla C, Roig B. Porphyria cutanea tarda induced by nelfinavir. Antiviral Therapy 2001; 6 (supl IV):71.

9. Ong ELC, Ellis ME, McDowell D, Gebril M, Weinkove C, Ead R. Porphyria cutanea tarda in association with the human immunodeficiency virus infection. Postgraduate Medical J 1988; 64:956-957.

10. The Norwegian Porphyria Centre (NAPOS). The drug database for porphyria. United Kingdom: NAPOS; 2007. [Cited 2012 January 31]. Available from: http:// www.drugs-porphyria.org/.

11. The American Porphyria Foundation (APF). Drug database: safe/unsafe drugs. [Internet]. Houston, USA: APF; 2010. [Cited 2012 January 31]. Available from: www.porphyriafoundation.com. [accessed January 31, 2012].

12. Associação Brasileira de Porfiria (ABRAPO). Medicamentos e a porfiria. [Internet]. Curitiba, Brazil: ABRAPO; www.porfiria.org.br/. 